\title{
SPINAL INJURIES IN RANGOON, BURMA
}

\author{
By Than Toe, M.B.B.S., D.Phys.Med.(Eng.) \\ Hospital for the Disabled, Rangoon, Burma
}

\section{Introduction}

THIS is the report about the incidence and problems of the spinal injury cases that were admitted to the Hospital for the Disabled, Rangoon, within October I975 and September 1976.

\section{Material}

The patients are mostly from the Rangoon Division and are first admitted to the Traumatology Ward in Rangoon General Hospital for rehabilitation.

The total number of patients admitted within a year was 36 and most of them are referred from the Rangoon General Hospital as shown in Table I.

As our rehabilitation hospital has only 50 beds, we have to give priority to young paraplegics. The complete high cervical injuries do not usually survive.

\section{Causes of Injuries}

The aetiological factors are shown in Table II. Most of the cases are due to a fall from height especially from trees, e.g. palm trees and coconut trees. The people make their living by climbing the palm trees daily to get the juices for making candy and drink.

Most of the cases are young male farmers who live in the villages and do not have proper houses, as in Tables III and IV. They live in huts made of wood,

\section{TABLE I}

Source of 36 patients referred to the Traumatology Ward

\begin{tabular}{lr}
\hline Rangoon General Hospital & 34 \\
Insein General Hospital & I \\
Self-referral & I
\end{tabular}

TABLE II

Aetiological factors

\begin{tabular}{lrr}
\hline \multicolumn{1}{c}{ Cause } & No. & $\%$ \\
\hline Fall from height & & $\%$ \\
Road traffic accident & 25 & 70 \\
Industrial accident & 2 & I2 \\
Sports, e.g. diving & 2 & 6 \\
Gunshot wound & I & 3 \\
Tunnel digging & I & 3 \\
\hline
\end{tabular}


TABLE III

\begin{tabular}{lr}
\multicolumn{2}{c}{ Age } \\
\hline Below 20 years & 3 \\
20-30 years & I2 \\
30-40 years & 10 \\
40-50 years & 9 \\
51 and above & 2 \\
\hline
\end{tabular}

TABLE IV

Occupation at the time of injury

\begin{tabular}{lr}
\hline Farmer & I I \\
Self employed & IO \\
Dependent & 6 \\
Labourer & 3 \\
Other & 6 \\
\hline
\end{tabular}

bamboos and palm leaves, and are built above the ground with a plinth of 3-4 feet. The accommodation ranges from two to three bedrooms with one sittingroom for a family whose members range from three to four children and wife and sometimes also with the members of the wife's family or his own. There is only one toilet which is usually built separately in the back of the garden.

The patients living in the city have a regular home and most of them have slight education. These patients can be rehabilitated socially and economically with less difficulty.

\section{Bony and Neurosurgical Lesions}

As shown in Tables V and VI, the majority of the cases are flexion injuries in thoraco lumbar area.

\section{Management}

The patients were treated conservatively with immobilisation on beds with pillows in hyperextension position in flexion injury cases for a period of 12 weeks. There was no incidence of deep vein thrombosis or pulmonary embolism during the period of immobilisation.

\section{TABLE V}

Bony lesion

\begin{tabular}{lr}
\hline Cervical I +2 & I \\
Other cervical & 3 \\
Thoracic & 3 \\
Thoraco-lumbar & 22 \\
Lumbar & 4 \\
No bony lesion & 3 \\
\hline
\end{tabular}


TABLE VI

Neurological lesion

\begin{tabular}{llr}
\hline Cervical & Complete & I \\
& Incomplete & 5 \\
TI-5 & Complete & I \\
& Incomplete & O \\
T6-I2 & Complete & I3 \\
& Incomplete & 4 \\
Cauda equina & I 2 \\
\hline
\end{tabular}

We applied a corset made of padded cow leather since Platezoate material is not suitable for our hot weather. Axillary crutches are usually given for low complete lesions as the elbow crutches are found to be difficult in ambulation on our uneven ground surfaces.

The toilets have to be re-arranged in one of the rooms in the house by building a toilet seat with handles as it is impossible for the paraplegics to use the outside toilet. The stairs have to be re-arranged and replaced by ramps for wheelchair mobility.

The patients can be assessed and taught for vocational training like tailoring, carpentry, cane work, weaving and radio mechanics so that they could be carried on in their own homes. There are co-operative shops set up by the Government so that the disabled people can sell their finished products.

The patients are accepted back in the family without much trouble and there are a lot of helping hands around in order to look after the patient.

\section{SUMMARY}

Spinal injuries in Burma as a result of a fall from height, especially from trees, in young male adults in low socio-economic classes; road traffic accidents are the second commonest cause; deep vein thrombosis and pulmonary embolism is very rare during the period of immobilisation. There are still some social problems of getting back to work and living conditions. We are trying our best to help the patients with spinal injuries.

\section{RÉSUMÉ}

En Birmanie, les lésions de la moelle épinière résultent des chutes d'une certaine hauteur, surtout des arbres chez les jeunes hommes adultes des classes socio-économiques inférieures; les accidents de la route sont la deuxième cause la plus commune; la thrombophlébite profonde et l'embolie pulmonaire est très rare pendant la période d'immobilisation. Il existe encore des problèmes sociaux lors du retour au travail et dans les conditions de vie. Nous essayons de faire de notre mieux pour aider les patients atteints de lésions spinales.

\section{ZUSAMMENFASSUNG}

Spinale Verletzungen bei jungen Menschen in Burma als Folge von Sturz from Bäumen sind die häufigsten Ursachen, Verkehrsunfälle am zweit häufigsten. Thrombose und pulmonale Embolie sind sehr selten während der Immobilisation. Soziale Probleme sind Lebensbedingungen und Rückkehr zur Arbeit. 